\title{
Consuming Argentina in the Name of Love: Cannibalism and Holy Communion in Carne by Eduardo Rovner
}

\section{Ariel Strichartz}

\begin{abstract}
What a refined expression of love, Saint Francis of Sales says, would we see in the act of a prince who, seated at his table, sent a portion of his meal to a pauper? And what if he sent him his entire meal? And what if he sent him his own arm to eat? In the Holy Communion, Jesus not only gives us part of his meal to eat, or part of his body, but his entire body.

- Bishop of Saint Agati dei Goti ${ }^{1}$
\end{abstract}

As the preceding passage by the Bishop of Saint Agati dei Goti (mid-eighteenth century) attests, the Eucharist, or symbolic consumption of Christ's flesh and blood, represents the supreme self-sacrifice in the name of love. ${ }^{2}$ Despite the Bishop's focus on the sublime nature of what is considered the most important sacrament of the Catholic faith, however, his description of the Eucharist suggests the potential for understanding the ritual of Communion as an act of cannibalism - a potential which theologians have avoided on the one hand by insisting that Christ's flesh and blood exist in the form of the Host and the wine used in the Mass; and on the other by describing the sacrament of the Eucharist as an act that dissolves the boundaries between man and Christ, a phenomenon that makes it difficult to determine who is eating whom. In fact, as Maggie Kilgour explains, both Communion and cannibalism, as manifestations of eating, are metaphors of incorporation in which the consumer seeks to absorb or subsume the Other. As such, both acts also share the paradoxical nature of eating; while eating implies the assimilation of an element by another more powerful body, the body is dependent on what is outside it for its survival. Furthermore, the 
consumption of one body by another obscures the limits between consumer and consumed, so that it is no longer clear whether one has control over the other (15). Sexual intercourse is a less extreme model of incorporation, given that the complete union of the two bodies in question cannot be realized fully without resorting to cannibalism (5-7). In his one-act play Carne (1985), the Argentine dramatist Eduardo Rovner collapses the acts of eating, taking Communion, cannibalism, and sexual intercourse, as María, the work's female protagonist, permits her lover to consume her breast in an attempt to satisfy his insatiable appetite and thereby secure his loyalty. ${ }^{3}$ In its conflation of the act of eating with the literal consumption, and thus disappearance, of a woman's body, Rovner's work recalls the violent treatment of the feminine body both in the discourse of the Argentine military dictatorship in power between 1976 and 1983 as well as in the practices of kidnapping and torture during the regime. Although the ambivalent nature of incorporation as it is portrayed in the play problematizes the relation of power between the male consumer and the consumed feminine body, ultimately Carne performs the misogynist violence of the junta enacted on the physical as well as symbolic level.

As in his other one-act plays that Rovner has denominated juguetes teatrales negros ${ }^{4}$ Carne builds on a realistic situation, gradually exaggerating it to such a degree that the spectators, even though they have witnessed (and are therefore complicit with) the development of the dramatic action, are shocked and horrified by the final outcome. The work's minimal action centers on a table, at which are seated Gordo and María. Next to the former lies a stack of dirty plates, yet Gordo continues to clutch his fork and knife, hungry for the next course. Lamentably, María informs him that he has eaten all the provisions purchased with his meager salary as a taxi driver. With the little she had left from the previous day's purchases she has invested in a bustier, which she proudly models for Gordo, pointing out the way in which it accentuates her bust. In fact, the bustier appears to achieve its objective: from this moment on, Gordo fixates on María's breasts, drooling, licking his lips, purring, scratching his fingernails across the table, and murmuring "carne." María, interpreting her lover's enthusiasm as sexual arousal, encourages him to bite her breasts. Yet Gordo finally succeeds in explaining that he really wants to consume ("comer de comer" 208) one of her breasts in order to sate at last his voracious appetite. Despite her initial repulsion, María eventually concedes to his desire for fear of losing his love. She removes her breast 
from the bustier and rests it on a clean plate, and the curtain falls as Gordo sprinkles salt over his next meal.

That an Argentine literary work should adopt meat as its principal trope is not unexpected, given the long-standing preponderance of beef in the country's economy, politics, and literary imagination. Cattle production has been pivotal in Argentina's economy since the Wars of Independence (Smith 1) and, as David Rock explains, early in the $20^{\text {th }}$ century both sheep and agriculture became secondary to cattle-related products in the nation's export economy $(133,169)$. The cattle industry's crucial role in the enrichment of the landed aristocracy, its contribution to the creation of the urban workforce, and its importance to the interests of foreign investors have linked it inextricably to Argentine politics (Smith 1-2). Due to its quality and its role in the nation's economy, beef represents the most important element of the Argentine diet as well as a source of national pride (Smith 2; Ostiguy and Armstrong 21). And while utilizing animal tissue as a metaphor is decidedly less lyrical than comparing a woman's teeth with pearls, for example, the visceral nature of meat, its preparation, and its consumption make it a useful symbol for commenting on violence and degradation, as Esteban Echeverría demonstrates in "El matadero" (written in 1839-1840 and published in 1871). Echeverría turns to the slaughterhouse and its accompanying carnage as an allegory for the bloody despotism of the Juan Manuel de Rosas regime, conveying the barbarism of Rosas's followers through their zeal for violence and their victimization of the heroic unitario, whom they torture and sodomize, ultimately reducing him to the status of the animals they butcher.

As Carne testifies, Echeverría's literary use of meat as a means of denouncing savagery has reappeared in the context of the so-called Dirty War. What is especially telling about Rovner's play is that, unlike "El matadero," it chooses a woman's body as the site of this carnage. ${ }^{5}$ In doing so, the play points to the discursive treatment of the feminine body and its physical corollary, the torture of the regime's feminized enemy, during the most recent military dictatorship. In her study of the intimate links between nationalism and gender identity during the Proceso, Diana Taylor argues that the violence of the Dirty War targeted the feminine body on both a figurative and literal level. Discursively, the junta described its nationalist project as a battle among men, played out on the feminine body. In addition to representing the nation as a weak and diseased feminine body, the regime metaphorically feminized the enemy by portraying any elements of opposition as female, weak, and therefore in need of the control of the healthy, male military. This rhetoric laid 
the basis for the actual torture of all bodies perceived as feminine, whether male or female. In the case of the latter, Taylor argues, the systematic assault on the organs of reproduction underscored the military's belief that the female body represented a threat to the military model of masculine strength and control (83-84). In Carne, Gordo's violation of María by consuming her breast echoes the pummeling of breasts described in accounts of torture. In the play, however, María's breast becomes a synecdoche for her body as a whole. As such, Gordo's desire to swallow and contain a part of his lover suggests her disappearance, echoing the kidnapping, torture, and assassinations carried out under the Proceso. María herself describes Gordo's desire as the wish to eliminate her entirely: “'Sí, claro! (Hablando hacia arriba, irónica) ¡Me adora! ¡Quiere hacerme desaparecer por su garganta y dice que me adora!" (209). María's ironic comments reveal that she knows all too well that the fulfillment of Gordo's fantasy implies her own annihilation.

In making the feminine body central to its dramatic action, Carne recalls as well the discursive practice employed by the dictatorship in its attempt to control women and determine their place in society. The junta defined as good women those who carried out the traditional roles of housewife and mother, busying themselves with domestic details such as feeding their families (Taylor 78; Laudano 24-25). While in Carne Gordo is defined by his hunger, María's most prominent feature is her breasts. As the initial stage notes indicate, María's generous cleavage, easily detected in the bustier, rests invitingly on the table (203). In addition to marking María as a sexual object, her breasts identify her as a mother figure capable of nurturing others. In fact, before she mistakenly believes that Gordo is sexually aroused, María's attitude towards him is maternal, concerned primarily with his nourishment.

It is no coincidence that María's name alludes to the self-abnegating mother por excelencia, the Virgin Mary. As Margaret Miles indicates, the popularity of the image of the Virgin nursing the infant Christ in Tuscan Early Renaissance culture may have had its origins in the chronic malnutrition and shrinking food supply of that period. Within such a context, viewers possibly received the image of the Virgin's one exposed breast as a symbol of nourishment (198). Although the contexts are markedly distinct, María's exposed breast in Carne could represent a symbolic panacea to Argentina's economic crisis during the military dictatorship. Under the economic policies implemented by José A. Martínez de Hoz, real wages plunged nearly 50 percent in 1976, while the price index rose by roughly 500 percent, with 
inflation remaining at over 150 percent through the late 1970s (Rock 367, 37071). In tracking the changes throughout the dictatorship in the consumption of various foods in the Argentine diet, Pierre Ostiguy and Warwick Armstrong assert that the consumption of virtually all foodstuffs diminished during the regime. Even the consumption of beef, which represented $24 \%$ of foodrelated expenses and therefore formed the most important element of the Argentine diet, dropped by 19.4 percent between 1976 and 1983 (50). ${ }^{6}$ In Carne, the difficulties that Gordo and María face in making ends meet hint at this economic crisis under the dictatorship. Driven to an act of cannibalism by his perpetual hunger, Gordo refers to the tantalizing sustenance suggested by María’s breasts: “¡Estoy harto de vivir aguantándome al lado de tanta abundancia!" (208).

While the image of the Virgin Mary suckling the baby Jesus underscores her maternal, self-sacrificing qualities, her ability to nourish others simultaneously lends her power, just as María's breast in Carne represents a solution to the couple's limited resources. In this way, the image of the nursing Virgin is dangerous for those wanting to perpetuate the control of women in a patriarchal order. As Margaret Miles indicates, "If the Virgin gained cosmic power by nursing her son, what was to prevent actual women from recognizing their power, derived from the same source, and irresistible to their adult sons?" (205). ${ }^{7}$ Thus, both in the context of fourteenth-century Tuscany and that of Argentina under the Proceso, those in power at the time felt it necessary to manipulate the image of the Virgin Mary in an attempt to insure their continued dominance. In the fourteenth century, the representation of Mary as submissive, humble, and obedient was presented as a model for actual women (Miles 200). In a similar manner, the military discourse of the Proceso presented the image of the Virgin Mary as an example for female citizens, especially mothers. Nevertheless, fourteenth-century religious discourse, threatened by the power suggested in the vision of the nurturing Virgin Mary, was quick to emphasize the unbridgeable gap between the ideal Virgin and actual women in an effort to block the latter's total identification with the Mother of Christ (Miles 206). Under the Proceso, this tension between associating with the figure of the ideal woman and being reminded of never reaching that ideal manifested itself on a violent and literal level. While on the one hand the discourse of the dictatorship elevated the image of Woman to a sublime level, on the other the practice of torture converted women into dispensable bodies devoid of personal identity, as Taylor elaborates: "In the concentration camp known as Olimpo (Olympus), the distinction between 
embodied and disembodied 'womanhood' (women/Woman) was made brutally evident as military soldiers tortured female prisoners in front of the image of the Virgen Mary" (83-84).

In Rovner's work, Gordo's desire to consume his lover's flesh in order to definitively alleviate his hunger makes the feminine body a site of power in yet another sense, evoking the idea of incorporation in which an external object is subsumed by another. In the series of metaphors for this process of incorporation outlined by Kilgour, the most basic model is the act of eating, and food comes to represent all other external substances that are consumed (6). Such an attempt to absorb what is outside, and therefore perceived as alien, expresses a nostalgia for a mythical unity in which there existed no destabilizing other to threaten inner stability (5). ${ }^{8}$ Yet, as Kilgour explains, this division between inside and outside on which incorporation is predicated disappears with the act itself, which dissolves the binary structure upon which it is based (4). In this way, the acts of incorporation analyzed by Kilgour (and enacted in Carne) - eating, Holy Communion, cannibalism, and intercourse - are accompanied by the conflicting urges of desire and aggression:

most acts of incorporation are extremely ambivalent, taking place between two extremes whose meeting seems very dangerous: a desire for the most intimate possible identification with another and a desire for total autonomy and control over others who are treated therefore as food, so that all exchanges are reduced to the alternatives of "eat or be eaten." (17-18)

As this passage suggests, it is not so inconceivable after all that the dramatic action of Rovner's play should begin with eating, suggest consummation, hint at Communion, and ultimately end in consumption.

Despite the carnivorous image with which Carne ends, the treatment of Gordo's hunger initially evokes the sacrament of the Holy Communion. Gordo frames his hunger in religious terms, representing himself as devout and imploring God to grant him María's breast as if it were a divine substance meted out by supernatural powers:

GORDO (gritando): ¡iQuiero comerme una teta!!...

(Mirando hacia arriba, como clamándole al cielo) ¡Sí, señor! ¡Una teta! ¿Por qué no?... (Cae al piso de rodillas y se toma las manos en actitud de rezo) ¡Por favor! ¡Nunca te pedí nada!...

¿O es mucho pedir para un cordero de Dios? (208-09)

While it is beyond the scope of this article to recount the vast theological scholarship on the sacrament of the Holy Communion, there are several 
aspects of Eucharistic thought that call into question the relation between consumer and consumed, and that are therefore particularly relevant for the analysis of Rovner's text. As St. Thomas Aquinas reasoned, while material food is absorbed by and therefore converted into the body that consumes it, the Host, as the body of Christ, has the power to spiritually transform the body that receives it: "Thus the effect proper to this Sacrament is the conversion of a man into Christ, so that he may no longer live, but Christ lives in him...." The relation between the Host and the body that receives it becomes even further obfuscated when one considers that Christians have "occasionally but persistently" reversed the above model, teaching instead that believers who received the Host actually were "consumed by Christ and digested into his body" (Morrison 9-10). Kilgour elaborates on this idea of "reciprocal incorporation:" "Both God and man play 'host,' a metaphor that itself has a variety of meanings which permit both identification and differentiation. Man is a host in that he literally takes God, in the form of the Host, into himself. But the Host is the kind of food that converts the feeder into himself..." (15). Furthermore, as the Italian historian of literature Piero Camporesi has demonstrated, a series of theological texts from the sixteenth century onward has characterized the Host as a superhuman nourishment capable of providing health and salvation (221). Indeed, in Carne, María cautions Gordo against eating more, fearful that his overindulgence will exacerbate his high blood pressure, diabetes, and liver ailments. As Gordo soon explains, however, María's flesh promises to cure him of such afflictions. The representation of María's flesh in Carne thereby challenges the perceived control of the consumer over what he or she has ingested, a theme that is key to the theological discussion of the Eucharist.

Thus, while the violent treatment of María's body in Carne echoes the military's representation of the nation as a feminine body, Rovner's work inverts the traditional association between the concepts of disease and the feminine. The regime's discourse represented the nation and the Argentine population as a sick female body, incapable of producing a healthy national being. As such, the country needed the aid of the masculine military junta in order to regain its health (Taylor 66-67). The play, however, twists the gendering of the military discourse: if María in Carne represents the patria, then it is the ailing military dictatorship, incarnated in Gordo, that is infirm. Furthermore, as the texts analyzed by Camporesi attest, the Host was thought to be "a mysterious food whose sweetness makes all creatures lose their 
appetite" (222), just as María's breast in Carne promises to sate Gordo's hunger once and for all:

GORDO: Todo lo que como...es para no comerme tu teta.

MARÍA: ¿Cómo?

GORDO (asiente): Si me la como, se me iría la desesperación por comer...y no tendríamos más problemas. (210)

In political and economic terms, María's flesh, with its power to cure hunger and physical ills, thus becomes tantamount to a horrific national solution. ${ }^{9}$

In fact, even behind cannibalism, which is generally regarded by those who do not practice it as barbarous and unconscionable, and therefore diametrically opposed to the sacred rite of Communion, lies the belief that the consumed flesh holds a special power. Peggy Reeves Sanday emphasizes that the power attributed to human flesh goes beyond its value as a mere foodstuff, since resorting to cannibalism to alleviate famine ("hunger cannibalism") is generally treated as morally reprehensible by even the very groups who engage in this practice (4-5). Rather, Sanday focuses her study on what she refers to as the "ritualized cannibalism" practiced by 156 societies, which she divides into two main types: those who eat enemies (exo-cannibals) and those who eat members of their own group, especially relatives (endo-cannibals). In the former, which more closely resembles the violent image of cannibalism in the collective imagination of non-cannibal groups, enemies (who must be foreigners) are eaten for vengeance. As Visser elucidates, however, the objective of such a destructive act is ultimately to usurp the power ascribed to the victim: "This power might be recognized and revered as useful energy, which is required by the good cannibal society that eats him [the victim] and will thus channel his force to useful purposes. To eat one's enemy is to 'take in' his power, to one's own increase" (14). While those who practice endocannibalism do not consume flesh, but rather ground-up bones or the ashes of the loved one's body, they share with the exo-cannibals a belief in the need to subsume the deceased in order to channel his/her essence (11-12).

The delicate balance between inside/outside and self/other manifested in Holy Communion and cannibalism emerges as well in sexual intercourse. As Kilgour points out, the impossibility of achieving absolute incorporation through sex may intensify desire, ultimately transforming it into aggression (8). Georges Bataille's description of eroticism evokes the ambivalent urges behind incorporation - desire and aggression - explored by Kilgour. For Bataille, living beings exist as separate, self-contained entities, discontinuous from one another. Continuity can be achieved only through eroticism and 
death, which succeed in dissolving the physical boundaries separating one being from another. Although eroticism may suggest either a union and/or reproduction and thus the promise of life, it simultaneously indicates the end of the participants as they previously existed, thereby evoking the violence of death. Thus, while for Kilgour intercourse is insufficient for incorporation, for Bataille eroticism holds the possibility for union. However, although Bataille describes the act of intercourse as a fusion and mingling of the participants, in his model the passive female is ravished by the active male and therefore ceases to exist as a self-contained entity, while her lover remains intact (17). As in Kilgour's model, a symbiotic melding of two bodies remains elusive, giving way instead to one entity's dominance over another.

What conclusion then are we to draw from the interaction between Gordo and María in Carne? Despite the fact that she is reduced to the equivalent of meat for consumption, María appears to have power over he who would ingest her, echoing the conflicting message created by the image of the nursing Virgin Mary, which patriarchal orders have struggled to control. Carne attempts to resolve this tension between the image of woman as on the one hand powerful and on the other submissive, by depicting María's suffering as masochistic. Because she concedes to Gordo's desire to eat her breast, the work suggests that María derives real pleasure from fulfilling his wishes, even if his pleasure implies her own destruction. From the outset, however, it is clear that her own desire is merely an extension of his, as in the case of the bustier: "Me lo compré para vos...Lo único que quiero es que te guste a vos" (205). Even this piece of clothing, the one item she has bought that he has not consumed, is really intended for him. As María indicates in the following exchange, she values Gordo's wishes over her own, and would give her life for him:

GORDO: ¿Mucho me querés?

MARÍA: ¡Seguro! Si sos todo para mí...No podría vivir sin vos.

GORDO: ¿Cuánto?

MARÍA: ¿Cuánto qué?

GORDO: ¿Cuánto me querés?

MARÍA: Más de lo que te podés imaginar...¿Querés que te diga?

¡Más que a mí misma!

GORDO: ¿Y qué darías por mí?

MARÍA: No sé...¿QQué querés de mí?

GORDO: No...Diceme vos, por favor te pido...¿QQué darías por mí? MARÍA (muy sensual): Lo que vos quieras. 
GORDO: ¿Darías...tu vida por mí?

MARÍA: Claro, mi loquito.

(Pausa)

GORDO: ¿Y un pecho? (206-07)

Gordo's insistence that María offer her breast to him, rather than simply agreeing to his wishes, underscores his need to see her surrender as the fulfillment of her own erotic desire rather than a capitulation to his wishes.

The unilateral relation disguised as a more equitable exchange that plays out between Gordo and María in Carne is suggestive of the often autoerotic experience of the Argentine torturer. In this merging of the carnal act with violence, the aggressor achieved autoarousal through the exploitation and domination of his objectified victim. Critical to the torturer's experience was the coerced participation of the victim, which in effect placed "her" (the feminized enemy) in the position of a partner ("a partner-object, a subject objectified"). Although the process may appear to be reciprocal, it is in fact reflexive for the perpetrator, who directs his actions towards himself (Graziano 156-57).

Rather than indicate his wish for a mutual exchange, Gordo's need to hear his own desires voiced by María signifies the autoerotic nature of his relation to her. Yet because her wishes are contingent on his, she is incapable of voicing her desire unless he has first stated his. Following Gordo's lead in what she mistakenly interprets as foreplay, María's reaction suggests that she experiences pleasure from suffering:

GORDO (tímidamente): Me los quiero comer.

MARÍA (muy sensual): Sí, claro que sí...Comételos, mi dulce...

GORDO: Comer...de comer.

MARÍA (pasándoselos por la cara): ¡Sí, sí! ¡Mastícamelos, papito!

GORDO: Te va a doler...

MARÍA: ¡Sí! ¡Quiero que me duela! ¡Matame! (207)

María's insistence that Gordo hurt and even kill her serves to dilute the power she has as nurturer and savior. In this way, Rovner's work echoes the junta's discourse described by Taylor in which the feminized population wanted and needed to be dominated by the masculine military (6). When she finally understands that Gordo wants to ingest her breast, María expresses disgust and horror. She acquiesces only when he explains that if he swallows a piece of her, she will no longer have to worry that he will leave her, as she will 
always be with him (210). Her submission, then, is born of fear, rather than an active voicing of her own desire.

Even the power that María has as representative of the Host is tempered by the violence enacted (or suggested) on her body. In the Eucharist, the individual who receives the Host is spiritually transformed by it, and becomes one with it (Camporesi 230). Indeed, in Carne, Gordo explains that his hunger for María's breast springs from his desire for a union with her:

GORDO: Pero, mi amor...Te quiero mucho...

MARÍA: ¡Dejame! Lo único que querés...es comerme.

GORDO: Quiero tenerte...(Pausa) dentro mío...

¿No es una prueba de amor? (210)

However, due to the power of María's flesh to transform Gordo, his desire to carry her inside of him expresses not love, but rather its aggressive counterpart: his need to assimilate her. This image of dominating the feminine body was central to the military junta's rhetoric during the Dirty War:

The corrupt and insidious feminine body needed to be contained and controlled. She could not be allowed to roam free. The female threat had to be eliminated in order to protect "women and children" and other good citizens who obediently conformed to patriarchal roles. (Taylor 75)

The final image of María about to be dismembered, just as the image invoked by the Bishop of Saint Agati dei Goti in this article's epigraph, more closely resembles an act of cannibalism than a sublime union, ultimately subverting the power suggested by the feminine body.

If in Carne María is sacrificed to save the ailing patria (Gordo), then what is the role of the work's spectators? Bataille explains that those witnessing a sacrifice share in the mystery revealed by the victim's death and are redeemed by watching his or her destruction (22). Carne constructs a spectator who can benefit from María's victimization only by being complicit with the work's violence. By suggesting that María wants and enjoys being dismembered and literally consumed by Gordo, the play perpetuates the idea that women's desire is always contingent on that of men. Furthermore, the work acts out the junta's rhetorical image of sacrificing Woman/women for the good of the patria.

And yet, as spectators we witness María's capitulation to Gordo's desire. Although it is clear that she acquiesces out of fear - fear of losing Gordo's love - she is instrumental in her own destruction. If María represents the patria and Gordo the Argentine military, then as members of the public 
we watch passively as the nation allows itself to be eaten alive by the military dictatorship, all in the name of love. The spectators of Carne, then, must confront their own complicity with the discourse of sacrifice perpetuated by the regime. ${ }^{10}$

In Carne, María's immolation in the name of love recalls Camporesi's description of the Holy Communion as a sacrifice in which the Omnipotent gives Himself as food (225). However, while the Eucharist connotes a bloodless sacrifice on a purely abstract level, Rovner's play renders the metaphor of consumption grotesque by performing it - in all its gendered splendor - on stage. In doing so, the work critiques the Christian discourse of sacrifice espoused by the junta. In the case of Carne, the annihilation of Woman/women proffers no redemption, spiritual or other: the public is left with a meaningless sacrifice that serves only to satiate a ravenous and self-pleasuring desire. Furthermore, the nation, as represented by María, is not a martyr nor any sort of participant engaged in the act for an ultimately redemptive purpose, but rather a pathetic figure complicit with the other's desire to devour it. Although Carne hints at the power represented by María's flesh, in the end the promise of communion gives way to senseless consumption as the nationalistic battle that Rovner stages around the table ultimately serves up the feminine body.

\section{St. Olaf College}

\section{Notes}

From Francis de Sales, Lettere spirituali (qtd. in Camporesi 234).

2 Margaret Visser elaborates on this idea of the Eucharist as ultimate sacrifice: "The Christian Eucharist (Eucharist means 'thanksgiving') was born directly from the Jewish Passover sacrifices. In it, animals are not killed because one message of the Eucharist is that, for believers, it re-enacts the conclusive sacrifice; neither human beings nor animals need ever be immolated again, because the thing has been done" (36).

Eduardo Rovner (b. 1942) has authored over two-dozen plays, many of which have been translated into various languages and staged internationally, and has won numerous prizes. He formerly served as General and Artistic Director of the Teatro Municipal General San Martín and is on the advisory committees of multiple artistic foundations. Since the appearance of his first work, Una pareja, in 1976, Rovner's corpus has displayed a progressive shift away from traditional realism as he draws on theatre of the absurd and other avant-garde tendencies; however, his work maintains a realistic premise overall in its critical treatment of both the decadence of the Argentine middle class and the authoritarianism of the Proceso (Pellettieri 21).

${ }_{4}$ ¿Una foto...? (1977); Concierto de aniversario (Teatro Abierto 1983); La vieja, la joven y el harapiento (Written for Teatro Abierto 1984.) 
5 It is important to note, however, that in "El matadero" Rosas's followers feminize the young unitario, contemptuously calling him a "cajetilla" (a pejorative label for a dandy from Buenos Aires) (88) and, even more significantly, sodomizing him. This feminization of the enemy reappears in the nationalistic discourse of the military dictatorship and the practice of torture under the regime.

6 I thank Nina B. Namaste for bringing this study to my attention.

7 Among the themes she treats in Jesus as Mother: Studies in the Spirituality of the High Middle Ages, Carolyn Walker Bynum analyzes the popularity of feminine imagery in twelfth-century religious texts produced by males. As she explains, while this "feminization of language" (2) dates back to the Old Testament, its preponderance in the High Middle Ages can be attributed to a newfound emphasis on the humanity of Christ $(125,129)$. Theologians of the period thus valued qualities traditionally associated with women, especially mothers, and frequently turned to them in their descriptions of Christ and (male) members of the clergy. The maternal attributes most invoked included the woman's ability to reproduce of her own matter; her sacrificial nature (she suffers in labor and birth); her loving and tender nature in a maternal sense; and her ability to nurture, or to feed her own children by nursing (131). Of particular relevance for this article, twelfth-century religious texts turned to images of nursing as a means of emphasizing the importance of nurturing in preaching. Of the multiple examples provided by Bynum, the following passage by Guerric abbot of Igny is illustrative of the power ascribed to the ability to provide sustenance through the feminine body, a theme played out as well in Carne: "The Bridegroom [Christ]... has breasts, lest he should be lacking any one of all duties and titles of loving kindness. He is a father in virtue of natural creation... and also in virtue of the authority with which he instructs. He is a mother, too, in the mildness of his affection, and a nurse" (Second sermon for SS. Peter and Paul, chap. 2, Sermons 2: 384-86; trans. the monks of Mount St. Bernard abbey, Liturgical Sermons 2: 155. Qtd. in Bynum 122).

8 Even without the conspicuous symbol of María's breast, Carne's preoccupation with the relationship between eater and eaten recalls Freud's first stage of sexual development. According to Freud, when the baby discovers that the mother's breast is an object separate from his/her body, rather than a part of itself as originally believed, he or she attempts to assimilate it once more. However, this urge to incorporate what is now perceived as alien is accompanied by the ambivalent urges of love and aggression (99). See Kilgour for an extensive discussion of Freud's theories of internalization.

9 In Carne, María recalls not only the self-sacrificing nature of the Mother of Christ, but also the dismemberment of Saint Agatha, one of the many Christian virgin martyrs who, as Karen A. Winstead explains, endured immolation in order to preserve her body for Jesus Christ (1). According to legend, having rejected the amorous advances of the Roman prefect Quintianus, Agatha (martyred 250 in Catania, Sicily) suffered a series of tortures, including having her breasts cut off. She is thus represented iconographically as holding her excised breasts on a platter (Kirsch; Jones), just as María in Rovner's work settles her breast on a clean plate for Gordo's consumption. Some speculate that Agatha is venerated as, among other things, patron saint of bakers due to the mistaken idea that she was carrying loaves of bread rather than her breasts ("St. Agatha"). Thus, the collapse of breast and bread in the representation of Saint Agatha parallels the Eucharistic consumption of María's breast in Carne, and iconographical representations of Saint Agatha, such as Francisco de Zurbarán's $17^{\text {th }}$-century rendition, pictorially underscore the violence directed against the feminine body in Christian hagiography, which Rovner stages in his dramatic work.

${ }^{10}$ In fact, when viewed in chronological order, Rovner's four juguetes teatrales negros can be seen to take up this issue of complicity with increasing intensity. Similar to Carne, the short works that precede it employ elements of the absurd, yet maintain an essentially realistic thesis as they question the double discourse in which the military regime, in the name of liberty, peace, and love for the nation, implemented a systematic campaign of repression. In ¿Una foto...? (1977), proud parents Luis and Alicia inflict violence on their baby in a desperate effort to capture its smile in a photograph. The musicianprotagonists of Concierto de aniversario (Teatro Abierto 1983) not only willfully ignore but also perpetuate human suffering, thereby acting against the very principles of liberty, peace, and happiness which they appear to honor in their interpretation of Beethoven's music. In La vieja, la joven y el harapiento (written 
for the 1984 cycle of Teatro Abierto), a contemptuous and uncompassionate Lady Liberty accidentally sets herself on fire with her torch, thereby becoming a foodstuff for the filthy and dark-skinned masses she scorns. While the dramatic action of all four plays dissolves into unchecked violence, as a whole the works display a shift in their treatment of complicity, initially focusing on those who directly inflict suffering on others and ultimately turning an accusatory gaze on those who knowingly permit their own destruction. In the final work, Carne, María is acutely aware of her impending annihilation, yet permits it in the name of love. Her role in her own death thus obligates the spectators to question their own complicity with the country's demise at the hands of the dictatorship.

\section{Works Cited}

Aquinas, Thomas. Commentary on Book IV of the Sentences. Qtd. in St. Thomas Aquinas on the Eucharist. The Crossroads Initiative. 23 Feb. $2007<$ http:// www.crossroadsinitiative.com/library_article/131/ST. THOMAS AQUINAS ON THE EUCHARIST.html>.

Bataille, Georges. Erotism: Death and Sensuality. Trans. Mary Dalwood. San Francisco: City Lights, 1986.

Bynum, Carolyn Walker. Jesus as Mother: Studies in the Spirituality of the High Middle Ages. Berkeley: U of California P, 1982.

Camporesi, Piero. "The Consecrated Host: A Wondrous Excess." In Zone: Fragments for a History of the Human Body. Ed. Michel Feher, et al. Vol. 1. New York: Urzone, 1989. 221-37.

Echeverría, Esteban. "El matadero." La cautiva / El matadero. Buenos Aires: Sur, 1962. 79-91.

Freud, Sigmund. "Anxiety and Instinctual Life." In New Introductory Lectures on Psychoanalysis. Ed. and trans. James Strachey. New York: Norton, 1965. 81-111.

Graziano, Frank. Divine Violence: Spectacle, Psychosexuality, and Radical Christianity in the Argentine "Dirty War." Boulder: Westview Press, 1992.

Jones, Terry H. "Agatha.” Patron Saints Index. Catholic Forum. 8 February 2008. $<$ http://www.catholic-forum.com/saints/sainta04.htm>.

Kilgour, Maggie. From Communion to Cannibalism: An Anatomy of Metaphors of Incorporation. Princeton: Princeton UP, 1990.

Kirsch, J.P. "St. Agatha." Catholic Encyclopedia. New Advent. 8 February 2008. $<$ http://www.newadvent.org/cathen/01203c.htm>.

Laudano, Claudia Nora. Las mujeres en los discursos militares: Un análisis semiótico (1976-1983). La Plata: Editorial de la Universidad Nacional de La Plata, 1995.

Miles, Margaret R. “The Virgin's One Bare Breast: Female Nudity and Religious Meaning in Tuscan Early Renaissance Culture." In The Female Body in Western Culture. Ed. Susan Rubin Suleiman. Cambridge, MA: Harvard UP, 1986. 193-208. 
Morrison, Karl F. “I Am You”: The Hermeneutics of Empathy in Western Literature, Theology, and Art. Princeton: Princeton UP, 1988.

Ostiguy, Pierre and Warwick Armstrong. La evolución del consumo alimenticio en la Argentina (1974-1984): Un estudio empírico. Buenos Aires: Centro Editor de América Latina, S.A., 1987.

Pellettieri, Osvaldo. Estudio preliminar. Teatro. By Eduardo Rovner. Buenos Aires: Corregidor, 1989. 9-44.

Rock, David. Argentina 1516-1982: From Spanish Colonization to the Falklands War. Berkeley: U of California P, 1985.

Rovner, Eduardo. Carne. In Teatro 2. Buenos Aires: Ediciones de la Flor, 1996. 201-11.

. Concierto de aniversario. In Teatro 2. Buenos Aires: Ediciones de la Flor, 1996. 187-99.

. La vieja, la joven y el harapiento. In Teatro 2. Buenos Aires: Ediciones de la Flor, 1996. 214-21.

. ¿Una foto . .. ? In Teatro 2. Buenos Aires: Ediciones de la Flor, 1996. 17386.

Sanday, Peggy Reeves. Divine Hunger: Cannibalism as a Cultural System. Cambridge: Cambridge UP, 1986.

Smith, Peter H. Politics and Beef in Argentina: Patterns of Conflict and Change. New York: Columbia UP, 1969.

“St. Agatha." Catholic Online. 2008. 8 February 2008. <http://www.catholic.org/ saints/saint.php?saint_id=14>.

Taylor, Diana. Disappearing Acts: Spectacles of Gender and Nationalism in Argentina's “Dirty War.” Durham: Duke UP, 1997.

Visser, Margaret. The Rituals of Dinner: The Origins, Evolution, Eccentricities, and Meaning of Table Manners. New York: Grove Weidenfeld, 1991.

Winstead, Karen A. Virgin Martyrs: Legends of Sainthood in Late Medieval England. Ithaca: Cornell UP, 1997. 